\title{
溶融亜鉛めっき鋼管の圧縮変形性状に関する研究 STUDY ON COMPRESSIVE DEFORMATION BEHAVIORS OF HOT DIP ZINC GALVANIZED STEEL PIPES
}

\author{
鈴木敏 郎*，佐藤 亘 宏**，深 沢 隆*** \\ Toshirou SUZUKI, Nobuhiro SATOH and Takashi FUKASA WA
}

\begin{abstract}
Yield stress of steel pipes became higher than that of plates because of work hardening; however, the apparent yield stress lower than that of the expected because of residual stress. And also in case of hot dip zinc galvanized steel pipes, thier deformation behaviors are alternated comparing with the raw materials since residual stress is partially released through the galvanizing.

This study quantitatively realized the effects of the galvanizing to compressive deformation behavior by residual strain measurements, tensile strength tests, and compressive strength tests of the series of short columns. Furthermore, we propose the limited value of thickness to diameter ratio of hot dip zinc galvanized steel pipe.
\end{abstract}

Keywords : hot dip zinc galvanized steel pipe, compressive deformation behavior, limited value of thick ness to diameter ratio

\section{1.はじめに}

冷間成形される鋼管部材の降伏応力度は，製造過程に おける加工硬化によって，原板の降伏応力度より高くな る一方, 残留応力が相当存在し見掛けの降伏応力度を下 げることは良く知られている。

この鋼管部材が防錆対策として溶融亜鉛めっき処理を 施される場合，製管のままの鋼管に比べて変形性状が変 化することが指摘されている。これは，めっき処理過程 において約 460 度の熱処理を受けることにより，製管時 の塑性加工において生じた残留応力が一部解除されるた めと考えられる。

したがって，溶融亜鉛めっき処理（以下めっき処理と 呼ぶ）を施した鋼管（以下めっき鋼管と呼ぶ）を構造物 に適用する場合，めっき処理が鋼管の圧縮変形性状に及 ぼす影響を定量的に把握しておくことが必要となる。

鋼管の圧縮変形性状に関する研究としては，日本鋼構

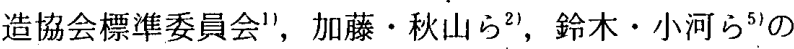
種々の方法で製造した鋼管短柱を対象とした圧縮試験研 究があり，製管のままの鋼管（残留応力を含む鋼管に分 類される），あるいは継ぎ目なし鋼管，焼鈍鋼管（残留 応力のない鋼管に分類される) それぞれについて，局部 座屈耐力, 変形能力等の諸性能と径厚比との関係を明ら かにしている。また，黒羽・越智6'は製管のままの鋼管
を対象に，材料特性を統計的に評価し，限界状態設計法 を念頭においた，確率統計論に基づく部材耐力，変形能 力の評価を行っている。

また，冷間成形される鋼管の残留応力あるいは残留応 力の圧縮変形性状に及ぼす影響に関する既往の研究とし ては，電縫鋼管に関するものが多く，加藤，青木ら゙1は， 製管過程を分析し，数理塑性学的取扱いにより残留応力 を推定し，見掛けの忍力とひずみの関係を調へてている。 また，青木，福本ら"は，残留応力の変形性状に及ぼす 影響と材料強度の不規則性について考察している。

しかしながら，めっき鋼管を対象とした圧縮変形性状 あるいは残留応力に関する研究は，筆者らの知る限りほ とんど行われていないのが実状である。

本研究では，まず鋼管の残留ひずみ計測を行い，めつ き処理が鋼管の残留応力に及ぼす影響を明らかにする。 続いて, 径厚比を変化させた短柱圧縮試験を行い, めっ き鋼管の局部座屈耐力, 变形能力等の諸性能之径厚比, 降伏応力度との関係を定量的に把握し，めっき処理に伴 う残留応力の変化加鋼管の諸性能に及ぼす影響を明らか にする。さらに，めっき処理により残留応力が一部解除 されることに伴う製管のままの鋼管に比べて変形性状が 変化する現象，あるいは降伏応力度が上昇する現象を考 虑し，めつき鋼管を対象とした許容応力度設計対応の径
* 東京工業大学工学部建築学科 教授 $\cdot$ 工博

** (株) 巴組鐵工所・工博

*** (株) 巴組鐵工所
Tokyo Institute of Technology Prof., Dr. Eng.

Tomoegumi Iron Works, Ltd., Dr. Eng.

Tómoegumi Iron Works, Ltd. 
厚比制限值を提案する。

\section{2. 残留ひずみ}

\section{1 残留ひずみ計測概要}

Table 1 に示す製管のままの鋼管，製管のままの鋼管 にめっき処理を施した鋼管， 600 度 1 時間加熱後炉冷す る方法による焼鈍処理を施した鋼管について，円周方向 表裏に等間隔に貼付したひずみゲージの周辺を，Fig.1 に示すように， $50 \mathrm{~mm}$ 方形に切断した場合の拘束開放 前後のひずみの変化から，材軸方向，円周方向それぞれ の残留軸ひずみ，曲げひずみを計測する。

鋼管の材質は，Table 2 に示すように，めっき割れ感 受性当量を従来鋼に対し低く押えたJIS G 3474 に規定 される鉄塔用高張力鋼管 STKT 60 鋼管（以後 HT 60 鋼 管と呼ぶ），JIS G 3444 に規定される一般構造用炭素鋼 鉘管 STK 41 鋼管の 2 種類の電释鋼管とする。

なお，溶融覀鉛めっき処理は以下の要領で行う。

(1)脱 脂 : 化成ソーダ, 80 90 度, 1 時間

(2)酸洗い : 硫酸, 60 度，0.5 1 時間

(3)フラックス处理：壏化亜鉛, 塩化アンモニウム, 60 度,

$$
2 \sim 3 \text { 分 }
$$

(4)めっき処理：垔鉛, 460 度, $3 \sim 5$ 分

(5)冷 却 : 温水, 60 度, 1 2 分

\section{2 めっき処理の残留ひずみに及ぼす影響}

Fig. 2 に（1）式により求めた残留軸ひずみ，最外縁 の曲げひずみの分布図を示す。

材軸方向軸ひずみ $\varepsilon_{T N}=\left(\varepsilon_{T 0}+\varepsilon_{T 1}\right) / 2$

円周方向軸ひずみ $\varepsilon_{L N}=\left(\varepsilon_{L 0}+\varepsilon_{L 1}\right) / 2$

材軸方向曲げひずみ $\varepsilon_{T M}=\left(\varepsilon_{T 0}-\varepsilon_{T_{1}}\right) / 2$

円周方向曲げひずみ $\varepsilon_{L N}=\left(\varepsilon_{L 0}-\varepsilon_{L 1}\right) / 2$

ただし， $\varepsilon_{T 0}, \varepsilon_{T_{1}}$ ：材軸方向計測ひずみ

$\varepsilon_{L 0}, \varepsilon_{L 1}:$ 円周方向計測ひずみ

添字の $T, L$ はそれぞれ材軸方向，以周方向を， 0,1 はそれぞれ鋼管外，内側を表す。

Table 1 に計測ひずみから（2）式を介して算定した
(1)硧管中央部において，シーム部を基潐とした 16 等分の外面に，材軸方向，円周 方向に一致させて二蚰しずみグージを貼付する。

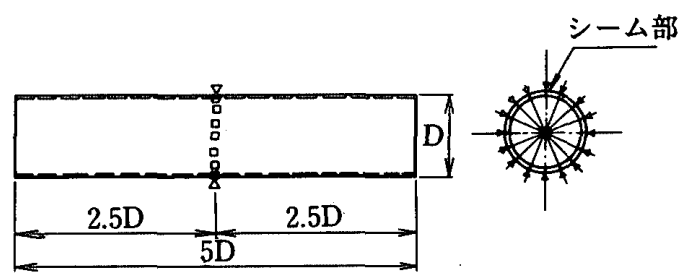

(2)型管中央部において，1．5 Dの幅にガス切断し，内面の外面と同样な位置に二 軸ひずみゲージを貼付する。
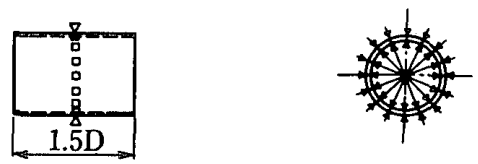

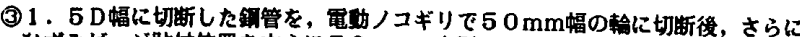
ひずみゲーシ䀡付位展を中心に50 mmの方形にスリット切断する。

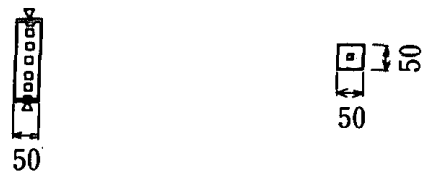

(4)ひずみは，それぞれゲージ貼付後の值を零点とする。これより，50 mm方形徐 の值との差か残留ひずみとなる。なお，ひずみ燝測ボイント番号はシーム部を起 点とする。

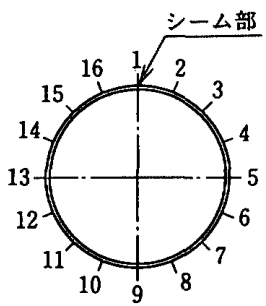

Fig. 1 残留ひずみ計測要領 ('16 分割の場合)

Table 2 HT 60 銅管成分表

\begin{tabular}{|c|c|c|c|c|c|c|}
\hline 政類の䟕号 & $\mathrm{C}$ & $\mathrm{S} \mathrm{i}$ & $\mathrm{M} \mathrm{n}$ & $\mathrm{P}$ & $\mathrm{s}$ & $\mathrm{N} \mathrm{b}+\mathrm{v}$ \\
\hline \multirow{2}{*}{ 含有比事 } & 0.12 & 0.40 & 2.00 & 0.030 & 0.030 & 0.15 \\
& 以下 & 以下 & 以下 & 以下 & 以下 & 以下 \\
\hline
\end{tabular}

1)管の炭索当蛙0.40\%以下とする。

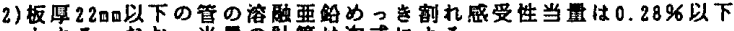

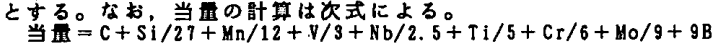

Table 1 残留ひずみ計測結果

\begin{tabular}{|c|c|c|c|c|c|c|c|c|c|c|}
\hline \multirow{2}{*}{ 試 } & \multirow{2}{*}{ 嘆 } & \multirow{2}{*}{\multicolumn{2}{|c|}{ 体 }} & \multirow{3}{*}{ 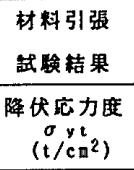 } & \multirow{2}{*}{\multicolumn{3}{|c|}{$\begin{array}{ccc}\text { 留 } & \text { U } \\
\text { 軸 方 向 }\end{array}$}} & \multicolumn{3}{|c|}{ 䊅 果 } \\
\hline & & & & & & & & & 周 方 & \\
\hline \#1 $1 x$ & $D / t$ & 材 西 & 起理方法 & & $\begin{array}{l}\varepsilon T \\
(\mu) \\
\end{array}$ & $\begin{array}{c}\sigma \mathrm{T} \\
\left(\mathrm{t} / \mathrm{cm}^{2}\right) \\
\end{array}$ & $\begin{array}{l}\sigma \mathrm{Y} \\
\sigma_{\mathrm{yt}} \\
\end{array}$ & $\begin{array}{l}E \mathrm{~L} \\
(\mu) \\
\end{array}$ & $\begin{array}{c}\sigma \mathrm{t} \\
\left(\mathrm{t} / \mathrm{cm}^{2}\right) \\
\end{array}$ & $\begin{array}{c}\sigma l \\
\sigma y z \\
\end{array}$ \\
\hline \multirow{3}{*}{$\phi 139.8 \times 4.5$} & \multirow{3}{*}{31} & \multirow{3}{*}{ STK 41} & 袃管のまま & 3.93 & 590 & 1.41 & 0.36 & 270 & 0.99 & 0.25 \\
\hline & & & めつを & 4. 31 & 250 & 0.76 & 0.18 & 260 & 0.77 & 0.18 \\
\hline & & & 距 & 3.49 & 130 & 0.35 & 0.10 & 70 & 0.25 & 0.07 \\
\hline \multirow{2}{*}{$\$ 216.3 \times 5.8$} & \multirow{2}{*}{37} & \multirow{4}{*}{ \&T60 } & 㽝管のまま & 6.44 & 1480 & 3.65 & 0.57 & 340 & 1.81 & 0.28 \\
\hline & & & め) & 6.20 & 910 & 2. 29 & 0.37 & 270 & 1.25 & 0.20 \\
\hline \multirow{2}{*}{$\phi 955.6 \times 5.8$} & \multirow{2}{*}{61} & & 筫のまま & 6.11 & 1110 & 2.85 & 0.47 & 420 & 1.74 & 0.28 \\
\hline & & & め ว ह & 6.20 & 860 & 2.22 & 0.36 & 340 & 1.38 & 0.22 \\
\hline
\end{tabular}

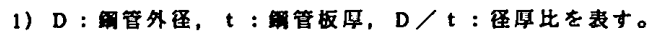

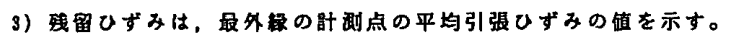

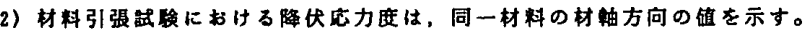

4)垡留灾力は，(2)式により求める。 
最外縁の平均残留応力度を示す。

材軸方向残留応力 $\sigma_{T}=E\left(\varepsilon_{T}+\nu \varepsilon_{L}\right) /\left(1-\nu^{2}\right)$

円周方向残留応力 $\left.\sigma_{L}=E\left(\nu \varepsilon_{T}+\varepsilon_{L}\right) /\left(1-\nu^{2}\right)\right\}$

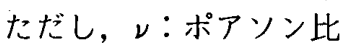

鋼管には, 計測值と逆符号の残留ひずみが内在し, 外 側引張, 内側圧縮となる。また, 残留ひずみは, 整管の 影響により，材軸方向，円周方向ともほぼ一様に分布す る。シーム部は，他の製管方法に比べて溶接入熱量が比 較的小さく部分焼鈍されることから，乱れは小さい。

いずれの鋼管においても材軸方向の曲げひずみが最も 大きく, その值は径厚比が小さいほど降伏応力度が高い ほよ゙大きくなる傾向にあり, 最外緣の残留応力度は, 製
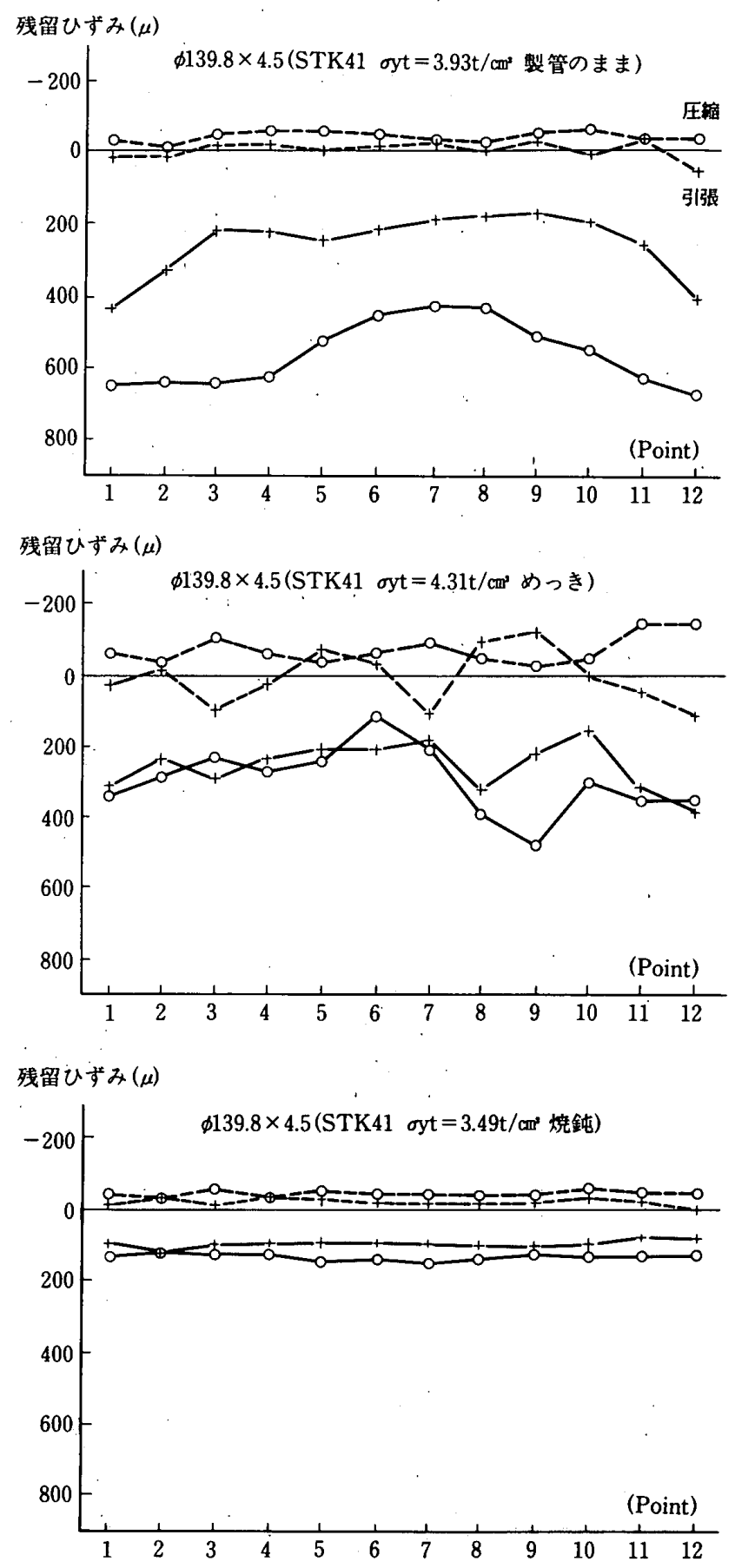

管のままの鋼管においては，材料引張試験から求まる降 伏応力度の $30 \sim 60 \%$ に相当する。

めっき鋼管の残留ひずみは，製管のままの鋼管に比べ て值の大きい材軸方向曲げひずみで $2 / 3$ 程度となり，い ずれも解放される傾向にあり，めつき処理による残留応 力の一部解除効果が認められる。

焼鈍鋼管の残留ひずみはほぼ解放されており，材軸方 向曲げひずみは製管のままの鋼管に比べ $1 / 4$ 程度とな る。

\section{3. 引張変形性状}

\section{1 材料引張試験概要}

Table 3 に示す，製管のままの鋼管，めっき鋼管，焼 鈍鋼管および原板を対象に，JIS Z 2241 に基づく材軸 方向, 円周方向の材料引張試験を行う。材料引張試験片 は, JIS Z 2201 金属材料引張試験片に基づき製作する。 なお，鋼管の円周方向について、は，JIS Z 3444 一般構 造用炭素鋼鋼管表一6 試験片の適用に準じて 5 号試験片 を適用する。

\section{2 めっ処理の応力度-ひずみ度関係に及ぼす影響}

Fig. 3 に代表的な試験片の応力度-ひずみ度関係曲線 を示す。

材軸方向においては，製管のままの鋼管は製管時に生

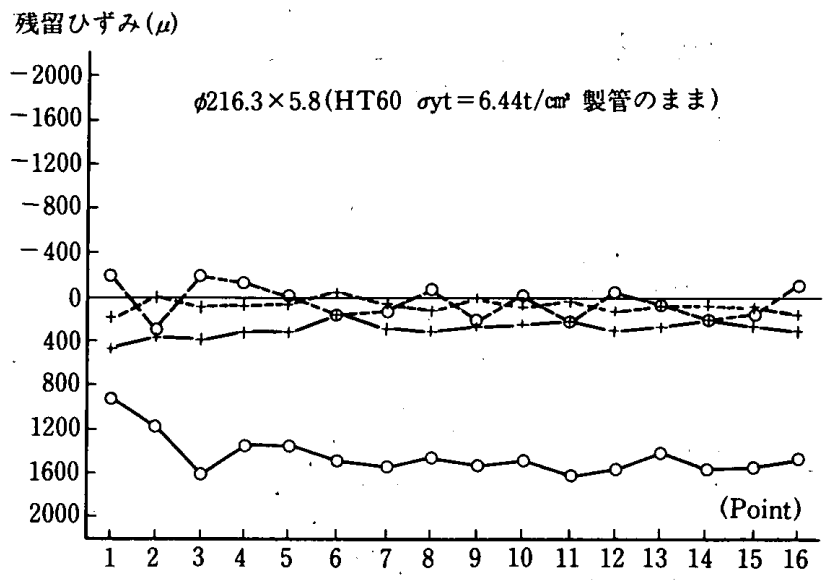

残留ひずみ( $(\mu)$

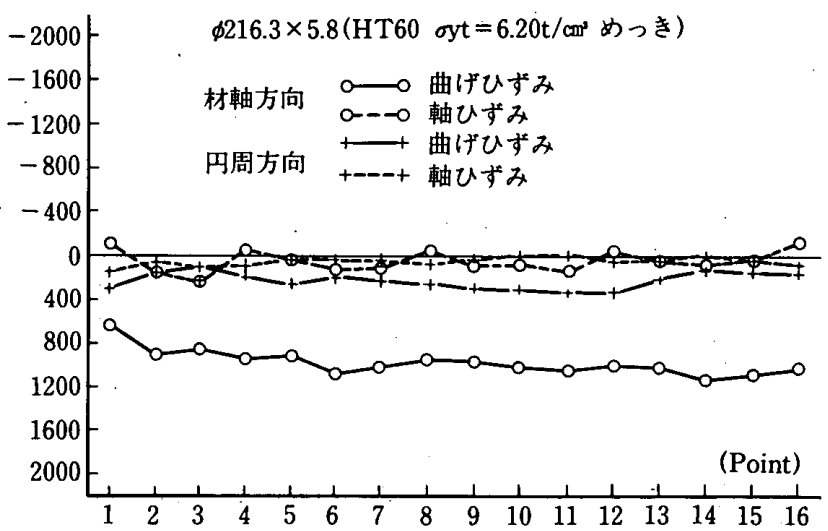

Fig.2 残留ひずみ分布図 
ずる残留応力が内在することから，降伏棚を有しない (RH) 型に，焼鈍鋼管は焼きなまし効果，あるいは高 温処理により残留ひずみがほぼ解放されることにより， 降伏棚を有する (EPH) 型に分類される。また，めっ き鋼管は後者に分類される。

一方，円周方向においては，製管のままの鋼管，めっ
き鋼管は降伏棚を有しない型に，焼鈍鋼管は降伏棚を有 する型となる。

なお，原板はいずれの方向も降伏棚を有する。

3.3 めっき処理の機械的性質に及ぼす影響

Fig. 4 に製管のままの鋼管の降伏応力度, 引張強さ, 伸び等の機械的性質（下添字 1 で表す）の原板（下添字

Table 3 材料引張試験結果

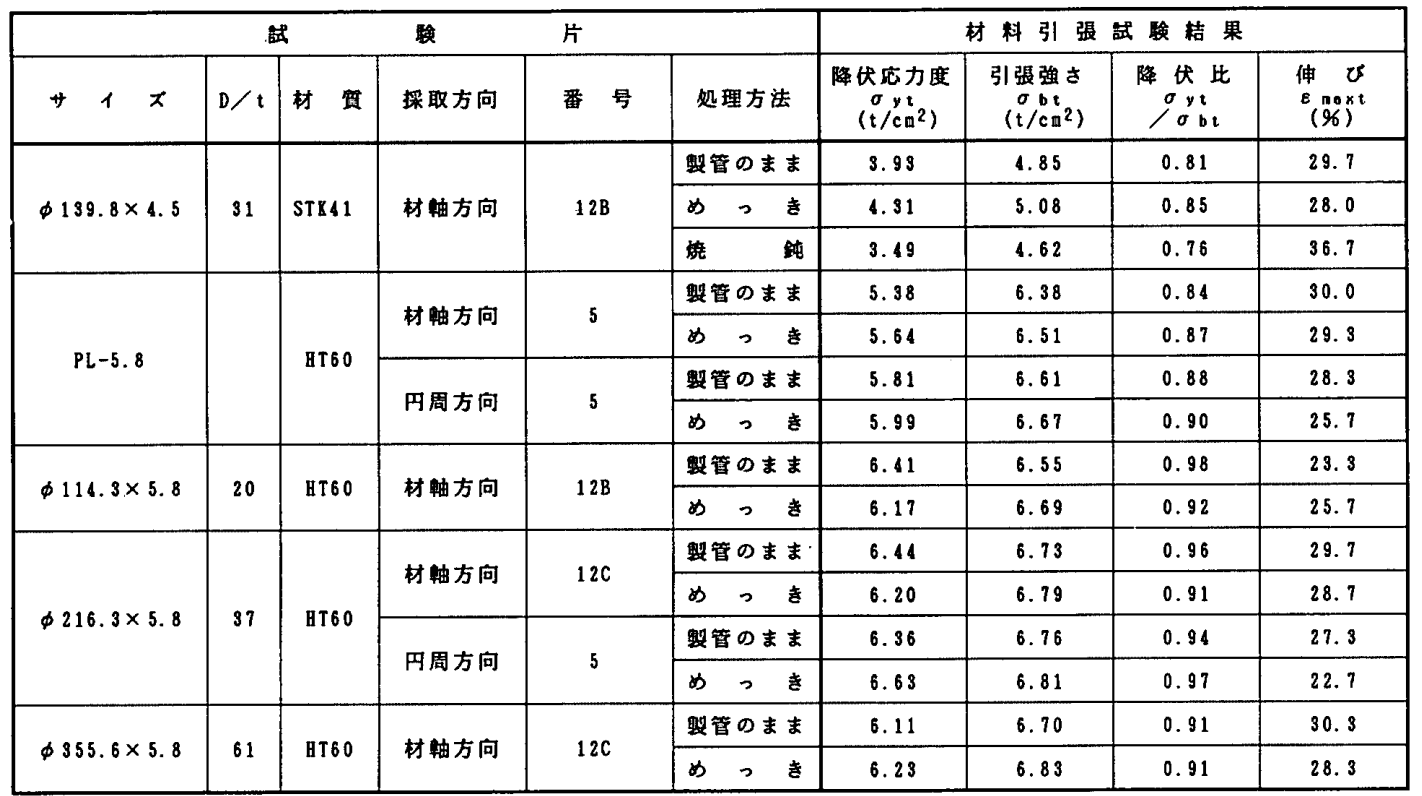

1) HT60船管は，日T60板（t=5.8吅）用いて管を行った。
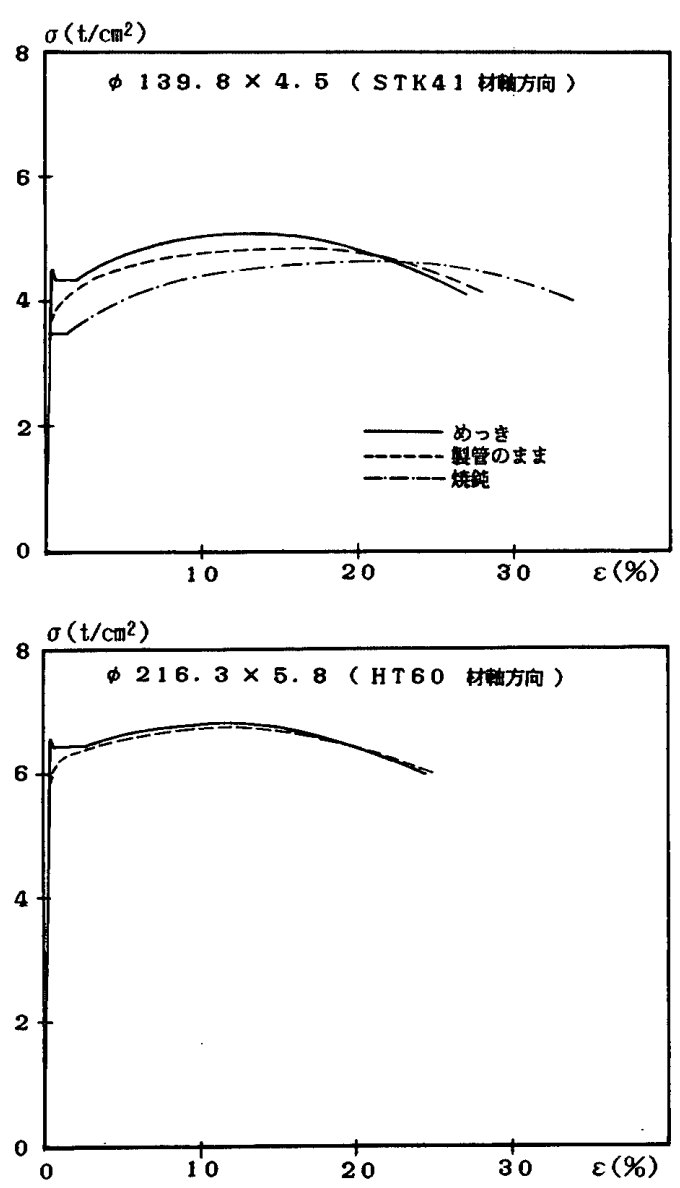

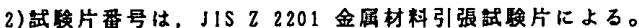
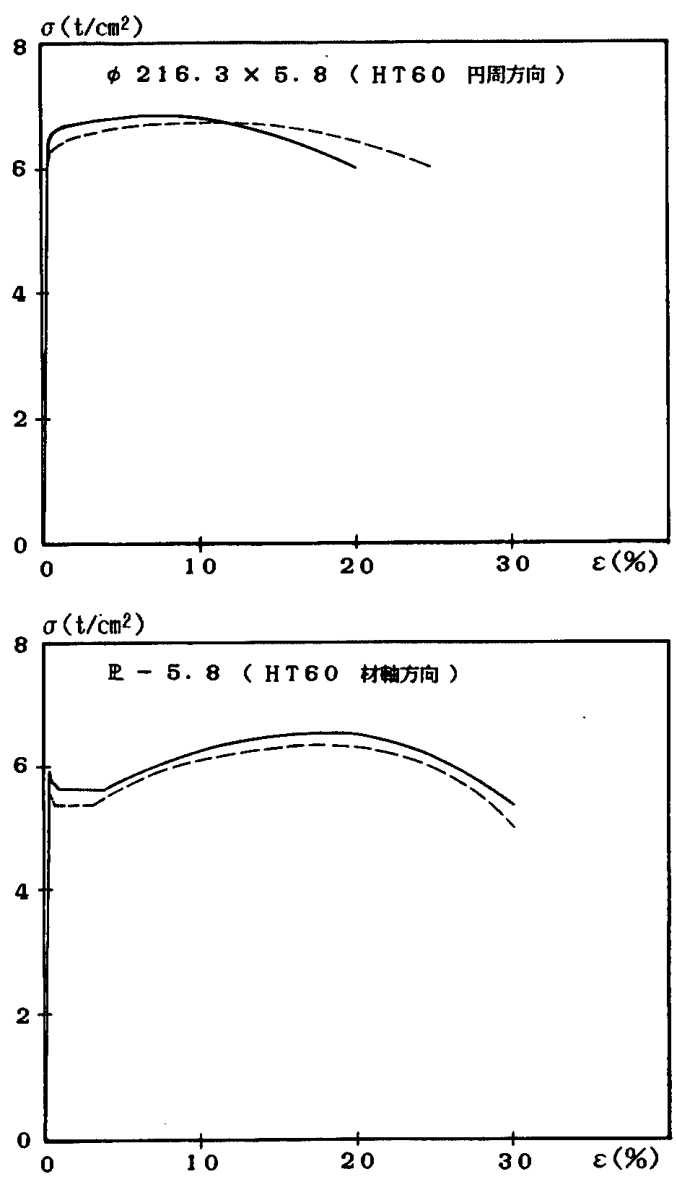

Fig. 3 応力度-ひずみ度関係（材料引張試験） 
0で表す）に対する比と鋼管の径厚比の関係を示す。こ のとき，図中の大きな口印のプロット点は本研究におけ る HT 60 鋼管の試験結果，小さい○印プロット点は既 往研究における STK 41 鋼管の試験結果”を示す。

製管のままの鋼管は，加工硬化の影響により，原板に 比べ降伏応力度が上昇し，その值は径厚比が小さいほど 大きい。一方伸びは逆に低下する。また，引張強さはほ とんど変化しない。

Fig. 5 にめっきした鋼管（図中白抜きプロット点）, 焼鈍した鋼管（塗り潰しプロット点）の機械的性質の製 管のままの鋼管に対する比と径厚比の関係を示す。この とき, 図中の大きなプロット点は本研究結果，小さいプ ロット点は既往の研究結果 ${ }^{11,8)}$ を示す。

めっき鋼管は, 降伏応力度, 引張強さ, 伸び共に製管 のままに比べて大きな変化は見受けられない。一方，焼 鈍処理を施した場合は, 加工硬化が解除されることから, 降伏灾力度は1〜2割程度低下し，逆に伸びは大きくな る。
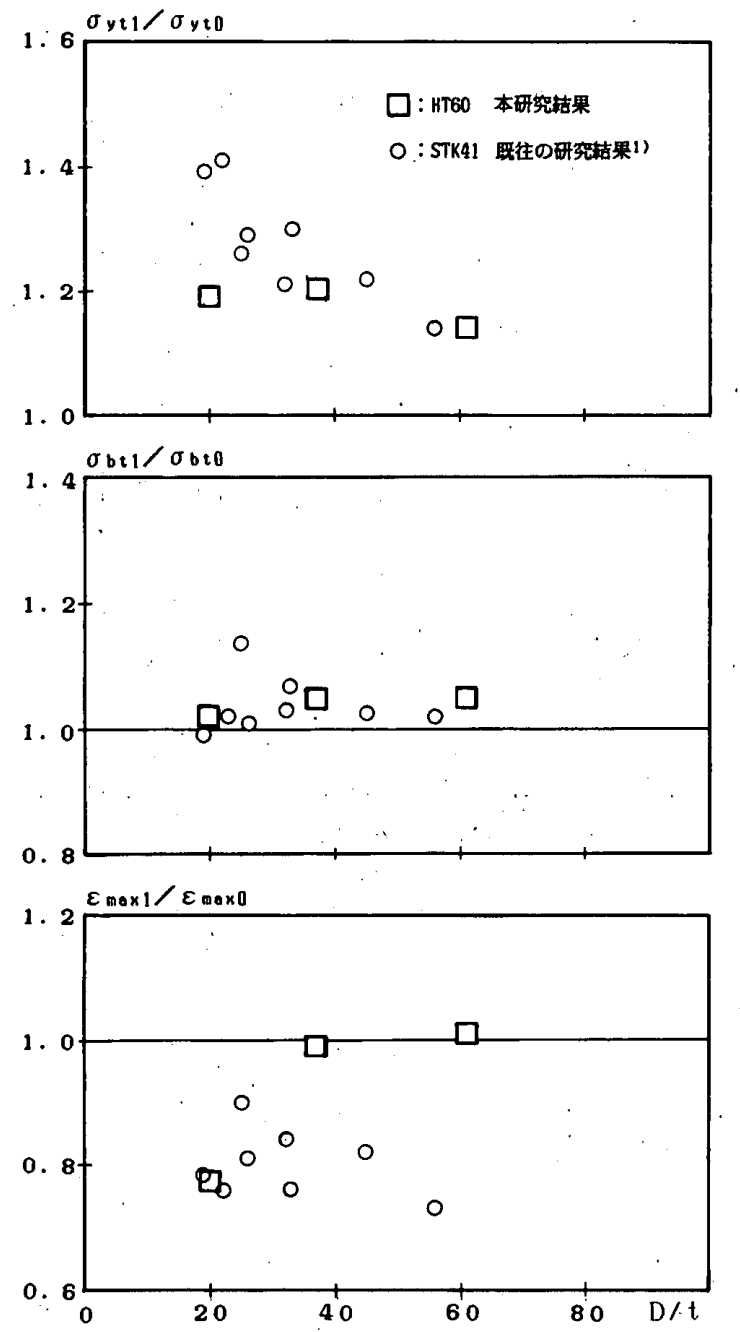

Fig. 4 製管のままの鋼管の機械的性質の原板に対する比

\section{4. 压縮変形性状}

\section{1 短柱圧縮試験概要}

Table 4 に示す製管のままの鋼管，めつき鋼管および 焼鈍鋼管について試験体長さ $3 \mathrm{D}$ の短柱圧縮試験を行 い, 局部座屈耐力; 変形能力, 耐力劣化剛性等の圧縮変 形性状を構成する因子と径厚比, あるいは降伏応力度之 の関係を定量的に把握する。

載荷は両端回転固定，平押しの条件で行い，中心圧縮 精度は初期段階における同一断面に貼付したひずみゲー ジ計測值により，（3）式に示す条件で管理する。

$$
\left(\varepsilon_{\max }-\varepsilon_{\min }\right) / \varepsilon_{\min } \leqq 0.1
$$

なお，同一鋼管を用い径厚比を変化させた試験体は， $\mathrm{HT} 60$ 鋼管で径厚比が小さい場合は，同一ロットで同 厚の板を用い径を変化させる方法により，また，その他 の場合は，径厚比の小さい鋼管の内外を削り出し板厚を 減ずる方法により製作する。

\section{2 めっき処理の応力度-ひずみ度関係に及ぼす影響}

Fig.6に，処理方法の異なる鋼管ごとに，径厚比を変 化させた応力度-材軸方向ひずみ度関係曲線を示す。こ のとき, 縦軸は応力度を同一シリーズの径厚比の小さい
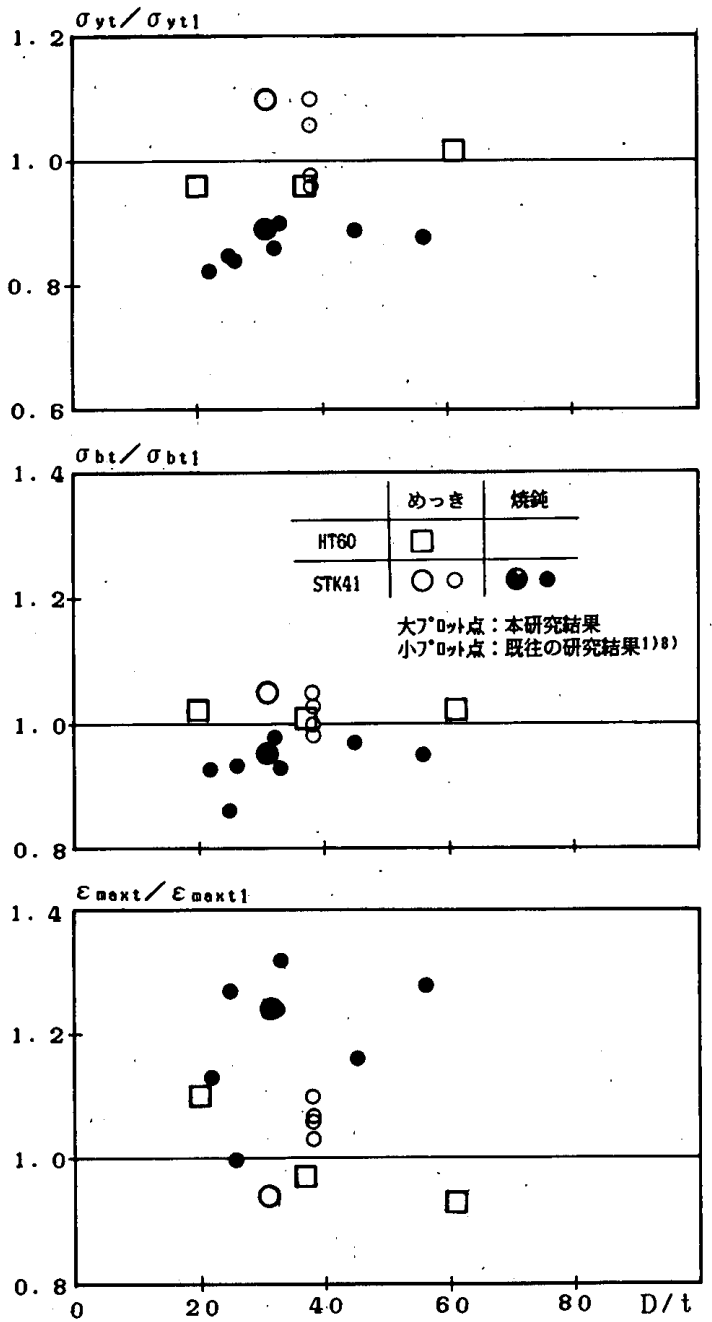

Fig. 5 めつき製管，焼鈍銅管の機械的性質の製管のままの鋼管 に対する比 
Table 4.1 短柱圧縮試験結果 (STK 41 鋼管)

\begin{tabular}{|c|c|c|c|c|c|c|c|c|c|c|c|}
\hline 試 & 䠁 & 体 & & & & 壮 代 樎 & 武 跧 桔 & $\overline{\text { 果 }}$ & & & \\
\hline$+1 x$ & $D / t$ & 処理方法 & $\begin{array}{c}0 \text { 伏力度 } \\
\sigma \quad y c \\
\left(\mathrm{t} / \mathrm{CD}^{2}\right)\end{array}$ & $\begin{array}{c}\text { 王㮌強さ } \\
\sigma \text { anxc } \\
\left(\mathrm{t} / \mathrm{co}^{2}\right)\end{array}$ & 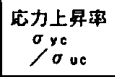 & $\begin{array}{c}\text { 降伏ひずみ } \\
\varepsilon \text { \& } \\
(\%)\end{array}$ & $\begin{array}{c}\text { 㞋大ひずみ } \\
\text { enanc } \\
(\%)\end{array}$ & $\begin{array}{c}\text { 变形能力 } \\
\varepsilon_{\text {yc }} \\
/ \varepsilon \text { noxc }\end{array}$ & $\begin{array}{c}\text { 劣化公国 } \\
E_{d} \\
(t / \cos )\end{array}$ & 坐屈モート & $a_{\mathrm{c}}$ \\
\hline \multirow{3}{*}{$\phi 139.8 \times 4.5$} & \multirow{3}{*}{31} & 管のまま & 3.76 & 4. 30 & 1.14 & 0.38 & 2.15 & 5.66 & 100 & syn. & 18.0 \\
\hline & & $\phi=6$ & 4. 13 & 4.41 & 1.07 & 0.20 & 2.60 & 13.00 & 100 & syø. & 16.0 \\
\hline & & 路 & 3.40 & 3.66 & 1.08 & 0.16 & 2.45 & 15.31 & 80 & syo. & 19.0 \\
\hline \multirow{2}{*}{$\phi 139.8 \times 3.3$} & \multirow{2}{*}{42} & 㽝管のまま & 3.66 & 3. 95 & 1.08 & 0.37 & 1.10 & 2. 97 & 130 & syo. & 13.7 \\
\hline & & めつ & 4.13 & 4. 21 & 1.02 & 0.20 & 0.66 & 3. 30 & 170 & вуд. & 12.1 \\
\hline \multirow{3}{*}{$\phi 139.8 \times 2.5$} & \multirow{3}{*}{56} & 紫管のまま & 3.12 & 3. 91 & 1.05 & 0.38 & 0.58 & 1.53 & 290 & syn. & 10.1 \\
\hline & & め $=$ ह & 4.13 & 4. 16 & 1.01 & 0.20 & 0.30 & 1.50 & 240 & syn. & 9.1 \\
\hline & & 神 & 3.40 & 9.42 & 1.00 & 0.16 & 0.27 & 1.69 & 210 & sya. & 11.0 \\
\hline \multirow{2}{*}{$\phi 139.8 \times 2.1$} & \multirow{2}{*}{67} & 曈管のまま & 3.74 & 9. 81 & 1.02 & 0.38 & 0.48 & 1.26 & 370 & sya. & 8.4 \\
\hline & & め & 4.19 & 4. 19 & 1.01 & 0.20 & 0.25 & 1.25 & 300 & syø. & 7.6 \\
\hline \multirow{3}{*}{$\phi 137.1 \times 1.7$} & \multirow{3}{*}{81} & 塗管のまま & 3.76 & 3.65 & 0.97 & 0.38 & 0.32 & 0.84 & 570 & syø. & 6.7 \\
\hline & & め つ き & 4.19 & 4. 18 & 1.01 & 0.20 & 0.21 & 1.05 & 740 & syo. & 6.2 \\
\hline & & 钝 & 3.40 & 3.40 & 1.00 & 0.16 & 0.17 & 1.08 & 340 & syn. & 7.6 \\
\hline \multirow{3}{*}{$\phi 136.5 \times 1.3$} & \multirow{3}{*}{105} & 㱔晏のまま & 3.76 & 3. 56 & 0.85 & 0.38 & 0.19 & 0.50 & 570 & syn. & 5.2 \\
\hline & & め $=\mathrm{E}$ & 4.13 & 4.16 & 1.01 & 0.20 & 0.20 & 1.00 & 1000 & sys. & 4.5 \\
\hline & & 钝 & 3.40 & 3.41 & 1.00 & 0.16 & 0.17 & 1.06 & 540 & sym. & 5.8 \\
\hline \multirow{3}{*}{$\phi 135.9 \times 1.1$} & \multirow{3}{*}{124} & 管のまま & 3.16 & 3.51 & 0.93 & 0.38 & 0.19 & 0.50 & 800 & asym. & 4.6 \\
\hline & & $\phi=$ ह & 4.13 & 4. 14 & 1.00 & 0.20 & 0.20 & 1.00 & 1330 & syn. & 3.9 \\
\hline & & 蚛 & 3.40 & 3.45 & 1.01 & 0.16 & 0.17 & 1.06 & 760 & syn. & 4.6 \\
\hline \multirow{3}{*}{$\phi 135.3 \times 0.9$} & \multirow{3}{*}{150} & 製管のまま & 3.76 & 3.25 & 0.86 & 0.38 & 0.17 & 0.45 & 2000 & asyo. & 3.2 \\
\hline & & めつき & 4. 13 & 3.65 & 0.88 & 0.20 & 0.19 & 0.95 & 2000 & asym. & 3.3 \\
\hline & & 跳 & 3.40 & 3.44 & 1.01 & 0.16 & 0.17 & 1.06 & 1200 & sym. & 3.9 \\
\hline
\end{tabular}

Table 4.2 短柱圧縮試験結果 (HT 60 鋼管)

\begin{tabular}{|c|c|c|c|c|c|c|c|c|c|c|c|}
\hline 跑 & 睶 & 体 & & & 短 & 拄 压 樎 & 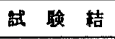 & 果 & & & \\
\hline$* 1 x$ & $D / t$ & 処理方法 & $\begin{array}{c}\text { 降伏应力度 } \\
\sigma y^{2} \\
\left(\mathrm{t} / \mathrm{cd}^{2}\right)\end{array}$ & $\begin{array}{c}\text { 王樎强さ } \\
\sigma a \Delta x c \\
\left(t / c^{2}\right)\end{array}$ & $\begin{array}{c}\text { 她力上暈事 } \\
\sigma \text { yc } \\
\sigma_{\text {oc }}\end{array}$ & $\begin{array}{c}\text { 降伏ひずみ } \\
\varepsilon \text { yc } \\
(96)\end{array}$ & $\begin{array}{c}\text { 履大ひずみ } \\
\varepsilon \text { noxc } \\
(\%)\end{array}$ & $\begin{array}{c}\text { 形能力 } \\
\varepsilon \text { ye } \\
/ e_{\text {moxc }}\end{array}$ & $\begin{array}{c}\text { 劣化公配 } \\
\text { Ed } \\
\left(t / c^{2}\right)\end{array}$ & 座闺モート & $\alpha_{\mathrm{c}}$ \\
\hline \multirow{2}{*}{$\phi 114.3 \times 5.8$} & \multirow{2}{*}{20} & 製䈏のまま & 5.83 & 6.62 & 1.14 & 0.48 & 2.57 & 5.35 & 80 & syo. & 18.3 \\
\hline & & め) & 6.44 & 7.02 & 1.09 & 0.31 & 3. 83 & 12.35 & 100 & syø. & 16.8 \\
\hline \multirow{2}{*}{$\phi 216.3 \times 5.8$} & \multirow[b]{2}{*}{37} & 笛管のまま & 5.33 & 5.93 & 1.11 & 0.45 & 1.21 & 2.68 & 230 & syn. & 10.6 \\
\hline & & めつ & 6. 29 & 6.29 & 1.00 & 0.30 & 0.45 & 1.50 & 220 & syn. & 9.4 \\
\hline \multirow{2}{*}{$6318.5 \times 5.8$} & \multirow{2}{*}{55} & 䨖管のまま & 5.29 & 5.67 & 1.07 & 0.15 & 0.82 & 1.82 & 450 & syn. & 7.2 \\
\hline & & め= & 6.17 & 6. 17 & 1.00 & 0.29 & 0.36 & 1.24 & 490 & syo. & 6.5 \\
\hline \multirow{2}{*}{$\phi 355.6 \times 5.8$} & \multirow{2}{*}{61} & 旼管のまま & 5.33 & 5.51 & 1.04 & 0.45 & 0.63 & 1.40 & 610 & syn. & 6.5 \\
\hline & & め) & 6.42 & 6.42 & 1.00 & 0.31 & 0.36 & 1.16 & 780 & sys. & 5.4 \\
\hline \multirow{2}{*}{$\phi 106.4 \times 5.8$} & \multirow{2}{*}{70} & 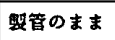 & 5.36 & 5.41 & 1.01 & 0.46 & 0.60 & 1.30 & 760 & syr. & 5.6 \\
\hline & & め? ま & 6.41 & 6.41 & 1.00 & 0.31 & 0.34 & 1.10 & 970 & syo. & 5.1 \\
\hline$\phi 108.0 \times 1.4$ & 77 & ஆつ & 6.44 & 6.31 & 0.98 & 0.31 & 0.31 & 1.00 & 1180 & syp. & 4.3 \\
\hline$\phi 107.5 \times 1.0$ & 108 & めつ ま & 6.44 & 6.18 & 0.96 & 0.31 & 0.30 & 0.97 & 1360 & asyn. & 3.0 \\
\hline$\phi 107.0 \times 0.8$ & 134 & め) & 6.44 & 5.32 & 0.89 & 0.31 & 0.25 & 0.81 & 1800 & asyn. & 2.5 \\
\hline$\phi 107.0 \times 0.7$ & 152 & めつを & 6.44 & 5.27 & 0.82 & 0.31 & 0.25 & 0.81 & 2100 & asya. & 2.2 \\
\hline$\phi 107.0 \times 0.5$ & 177 & め, & 6.44 & 4.97 & 0.77 & 0.31 & 0.24 & 0.71 & 2600 & asyn. & 1.8 \\
\hline
\end{tabular}

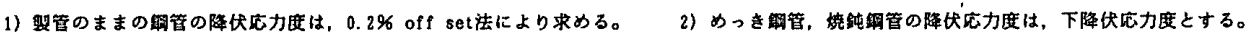

また、降代ひずみは，次式にて束める。 $\varepsilon y=\sigma y c / E+0.2 \%$ また，降伏ひずみは次式にて求める。 $\varepsilon y=\sigma y c / E$

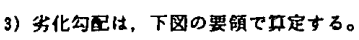

4)坐届モートは対称形の场合は8yロ，非対称の倜合は asya.で表示する。

5)バラメータ $\alpha$ のの定には実断面寸法を用いる。

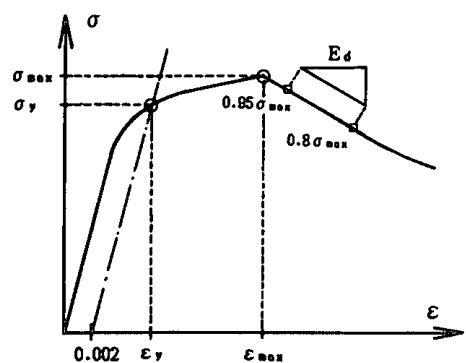

残留応力を合む鎮管

(㹕管のままの銅管)

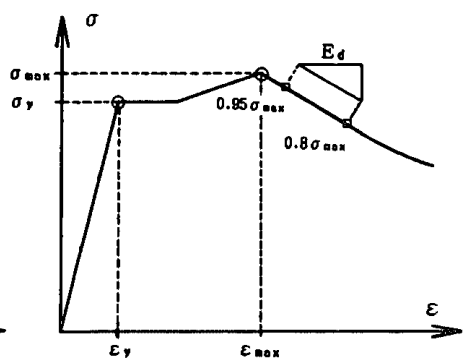

残留喥力のない知管

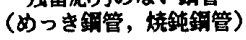


試験体の降伏応力度で除すことにより無次元化する。ま た，横軸のひずみ度は試験体の全変形量 $\delta$ を長さ 1 で 除した值とする。

製管のままの鋼管は，径厚比にかかわらず降伏棚を有 しない（RH）型となる。また, 焼鈍鋼管は, 径厚比が 小さい場合は降伏棚，ひずみ硬化域を有する(EPH) 型となるが, 径厚比が大きい場合はひずみ硬化域まで至 らず座屈する (EP) 型となり, さらに大きくなると明 瞭な降伏棚が存在しない（E) 型となる。

これに対し，めっき鋼管は，材軸方向の材料引張試験 之同様, 後者に分類され, 応力度一ひずみ度関係の面か らは残留応力を含まない鋼管に属する。

なお，いずれの場合においても，径厚比が小さいほざ 変形性状は良好となる。
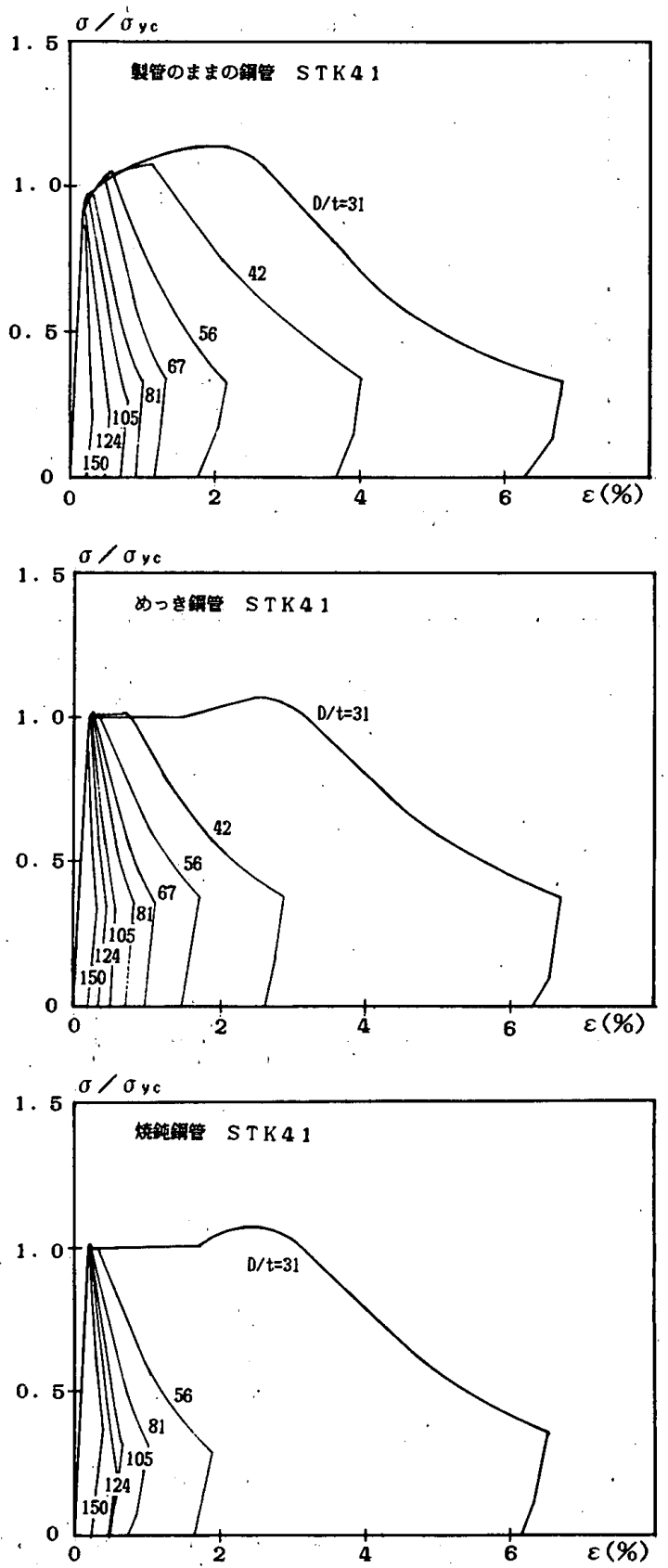
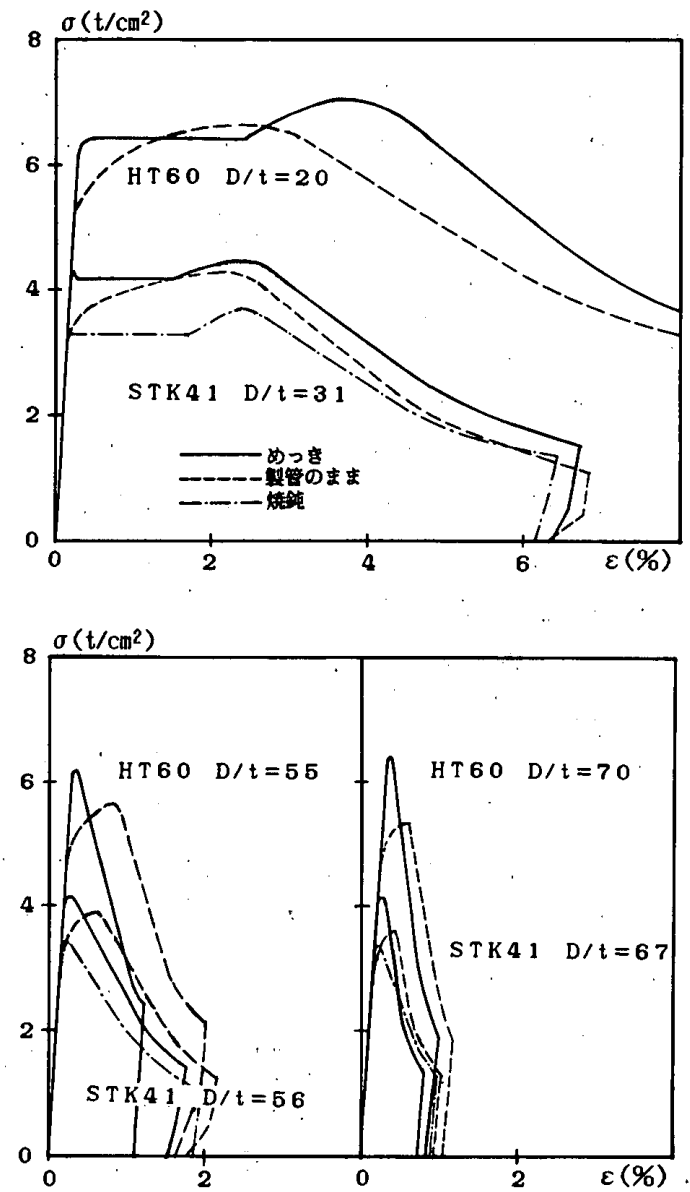

Fig.7 応力度一ひずみ度関係（短柱圧縮試験） [処理方法を変化させた場合］
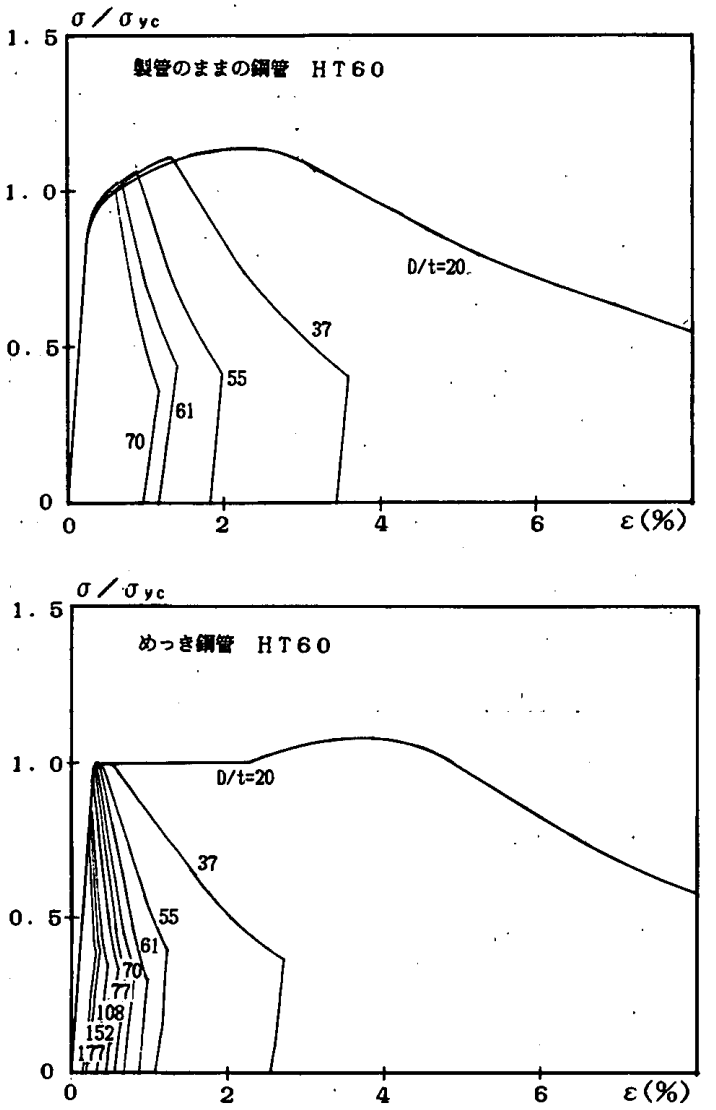

Fig. 6 応力度-ひずみ度関係（短柱王縮試験）[径厚比を変化させた場合] 
試験体の座屈モードは, 径厚比が非常に大きく降伏応 力度を下回る場合は非対称モードとなるが，それ以外は 上端部あるいは下端部においていわゆる堤灯型の軸対称 モードとなる。

\section{3 めっき処理の諸性能に及ぼす影響}

Fig. 7 に処理方法を変化させた場合の态力度一材軸方 向ひずみ度関係を径厚比ごとに示す。

最大応力度の大きさは, 径厚比にかかわらずめっき> 製管のまま>焼鈍の順となるのに対し, 最大応力度に対 応するひずみ度は, 径厚比が小さい場合はめっきう焼鈍 >製管のままの順，大きい場合は製管のまま>めっき 焼鈍となり，径厚比により様相が異なる。

Fig. 8 に，製管のままの鋼管の最大応力度が降伏応力 度を上回る場合における，製管のままの鋼管の原板（材 料引張試験結果）に対する降伏応力度比之径厚比の関係 を示す。なお，製管のままの鋼管の降伏点は $0.2 \%$ offset 法により求める。また, 径厚比が大きく降伏点が 明確に求まらない場合は, 同一材料からなる径厚比の小 さい試験体の降伏点と同値として扱う。

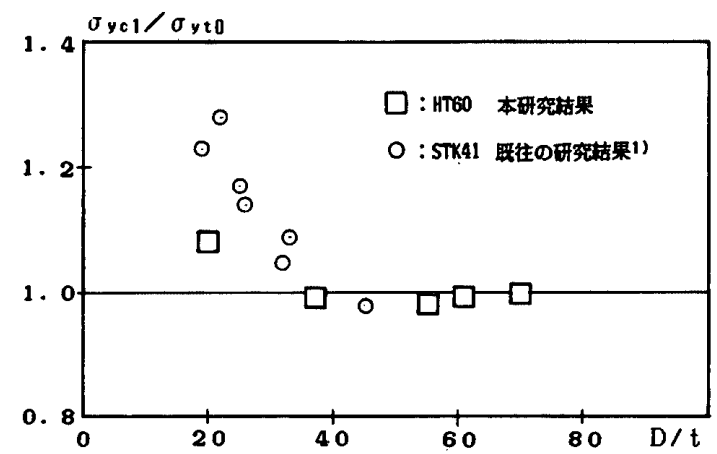

Fig. 8 製管のままの鋼管の降伏応力度の原板に対する比

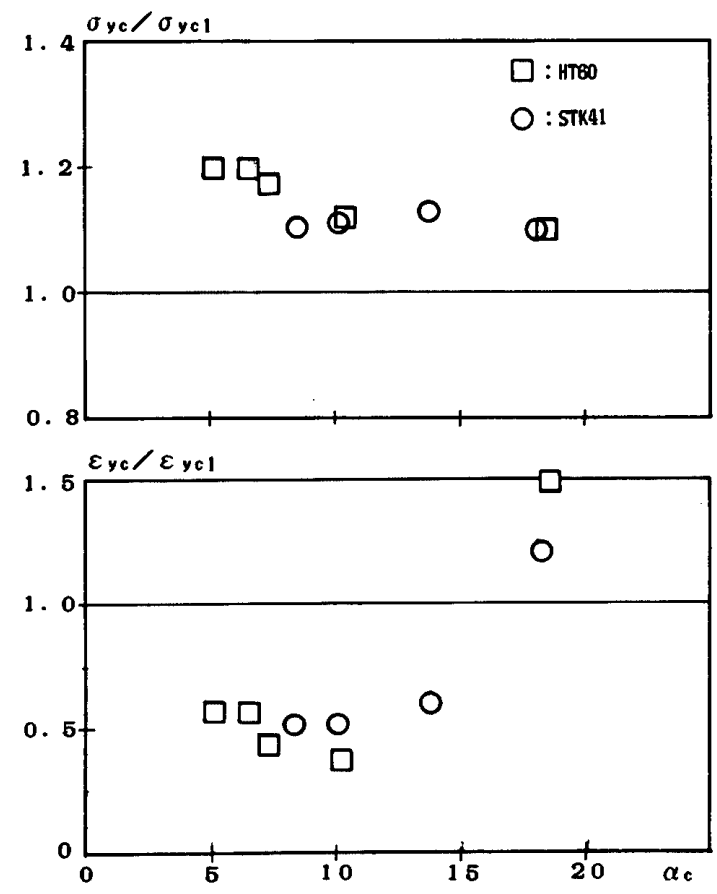

Fig. 9 めつ鋼管の諸性能の製管のままの鋼管に対する比
鋼管の降伏応力度は, 径厚比が 40 を下回る場合は加 工硬化の影響により原板より大きくなるが, 径厚比が 40 より大きい場合は，おおむ敉等しい值となる。

Fig. 9 にめっきした鋼管の製管のままの鋼管に対する 降伏応力度, 最大応力度に対応するひずみ度の比と (4) 式で定義するパラメー夕 $\alpha_{c}$ の関係を示す。

$$
\alpha_{c}=E /\left(\sigma_{y c} \cdot D / t\right)
$$

めっき鋼管の降伏応力度は製管のままの鋼管のそれを 1 2 割程度上回る。また, ひずみ度はパラメータ $\alpha_{c}$ の 大きい領域では上回るのに対し，小さい領域では逆に下 回る。

\section{4 圧縮変形性状の定式化}

Fig. 10 にパラメー夕 $\alpha_{c}$ と応力上昇率 $\left(=\sigma_{\operatorname{maxc}} / \sigma_{y c}\right.$, $\sigma_{\max c}$ : 最大応力度, $\sigma_{y c}$ : 降伏応力度) の関係, Fig. 11 に変形能力 $\left(=\varepsilon_{\max c} / \varepsilon_{y c}, \varepsilon_{\max c}\right.$ : 最大応力時ひずみ度,
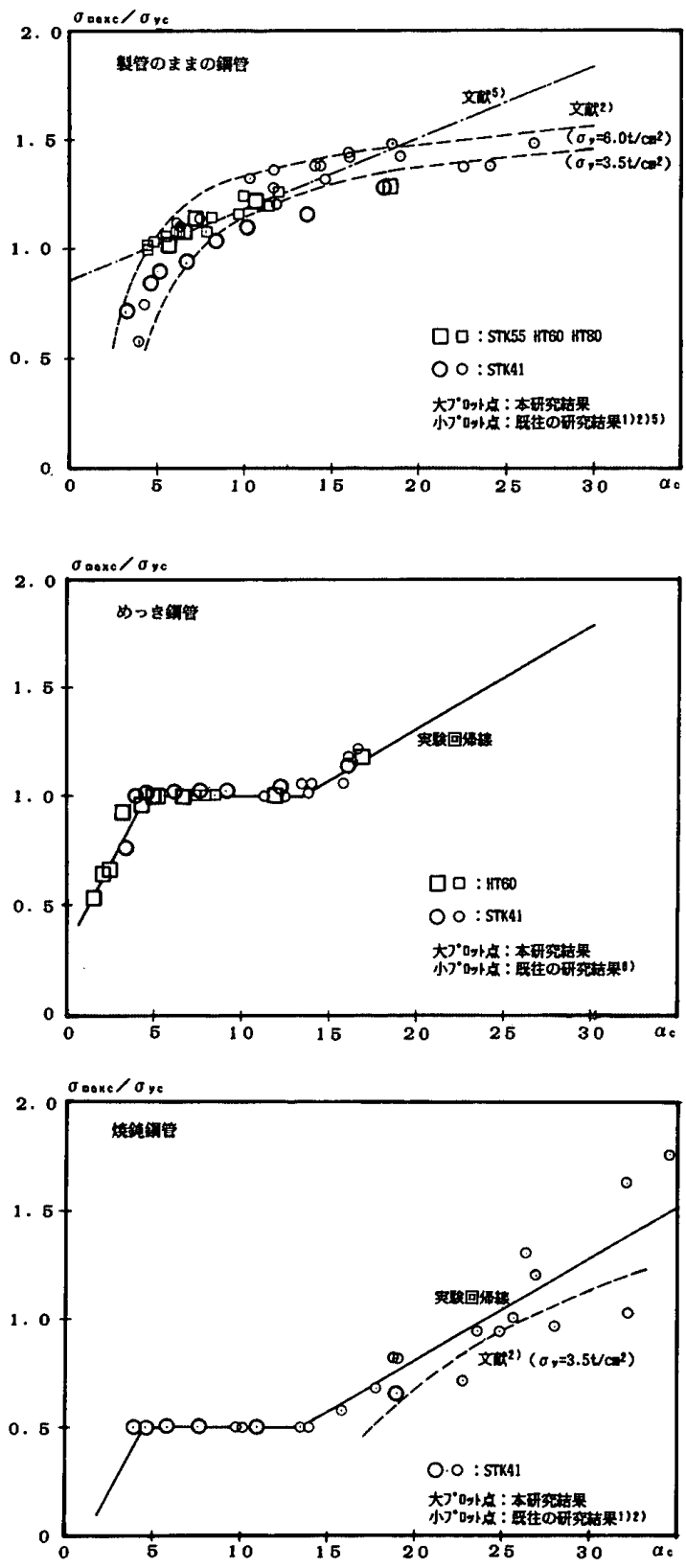

Fig. 10 応力上昇率上パラメータ $\alpha_{c}$ の関係 

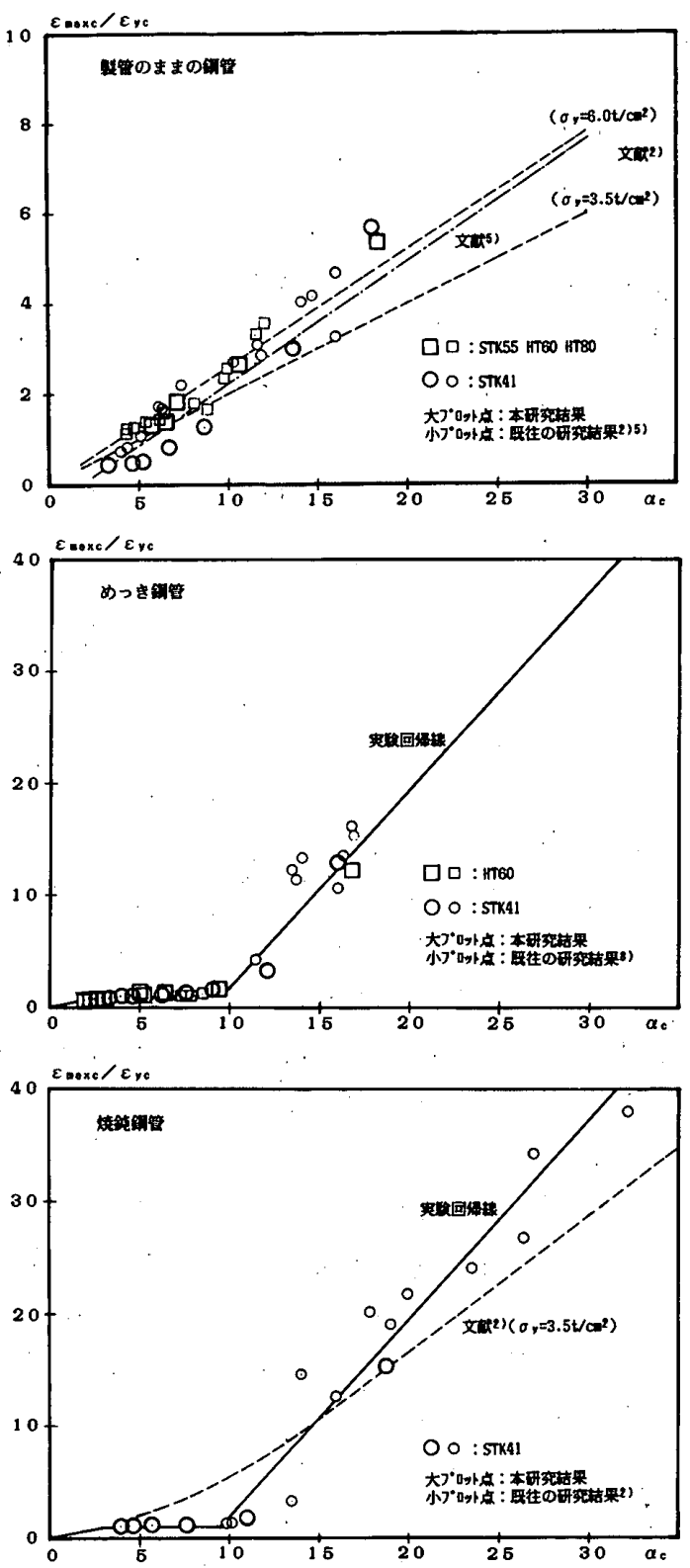

Fig. 11 変形能力とパラメー多 $\alpha_{c}$ の関係

$\varepsilon_{y c}$ ：降伏点に対応するひずみ度）との関係，Fig. 12 に 耐力劣化勾配. $\left(E_{\alpha}: t / \mathrm{cm}^{2}, 0.95 \sim 0.8 \sigma_{\operatorname{maxc}}\right.$ 間の平均劣 化剛性) との関係を示す。このとき, 図中の大きなプロッ 卜点は本実験結果，小さなプロット点は既往の研究結 果 ${ }^{11,21,51,81}$ ，実線は実験回帰線，点線，一点鎖線は既往 の研究21,5)における実験式を示す。

なお, 応力上昇率, 変形能力等の諸性能は文献 1), 5) に準じて定義するものとする。したがって，ここでいう 変形能力は, 骨組の変形能力を算定する場合の部材の累 積塑性変形倍率の完全弾塑性形の復元力特性への換算 值 ${ }^{91,101}$ とは異なった定義となる。

いずれの場合もパラメータ $\alpha_{c}$ と強い相関関係にあり, 応力上昇率，変形能力に関する製管のままの鋼管の 既往の実験式は一本の曲線で表されるのに対し，めっき 鋼管における実験回帰線は，焼鈍鋼管と同様，3 本の直
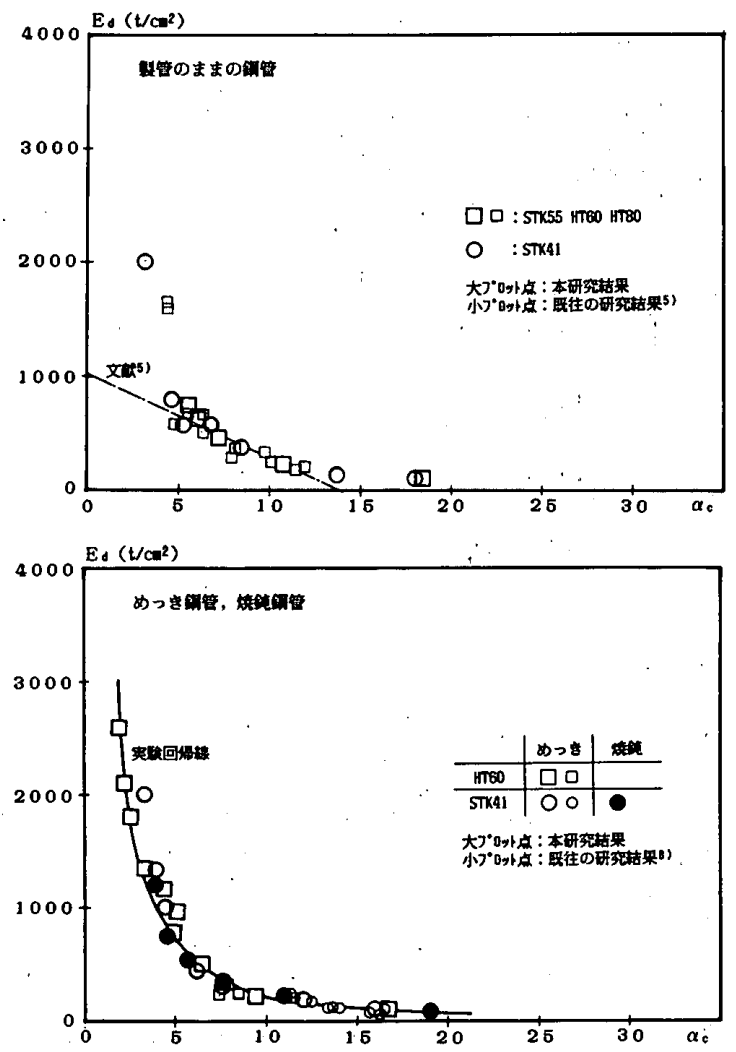

Fig. 12 耐力劣化勾配とパラメータ $\alpha_{c}$ の関係

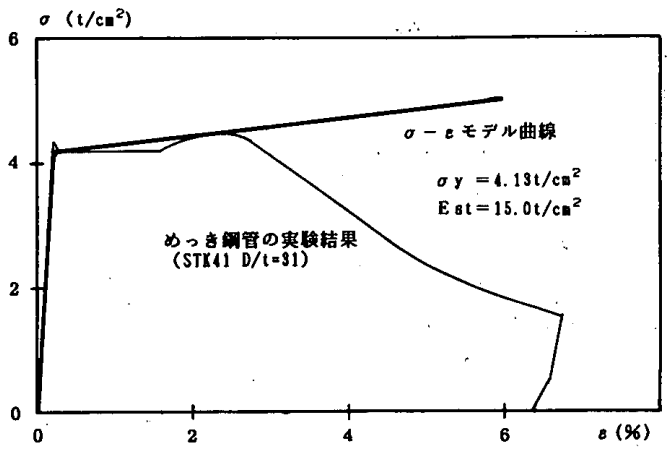

Fig.13 応力度-ひずみ度関係のモデル化

線で表されることから，めっき鋼管は残留応力のない鋼 管として取り扱える。

めっき鋼管，焼鈍鋼管において，パラメータの大きい 折点（第一折点）より大きい領域においては変形性状は 良好であり，パラメータの小い折点（第二折点）より 小さい領域においては非対象座屈で屈服し変形性状は劣 る。

なお，耐力劣化剛性は，いずれの場合においても一本 の曲線で表され，処理方法による差異は見受けられない。

\section{5 残留応力の圧縮変形性状に及ぼす影響}

残留応力, 特に材軸方向曲げ応力の圧縮変形性状に及 ぼす影響を明らかにすることを目的として，文献 5）に 概要を示す軸対称シェル要素による弾塑性大変形解析を 行う。 


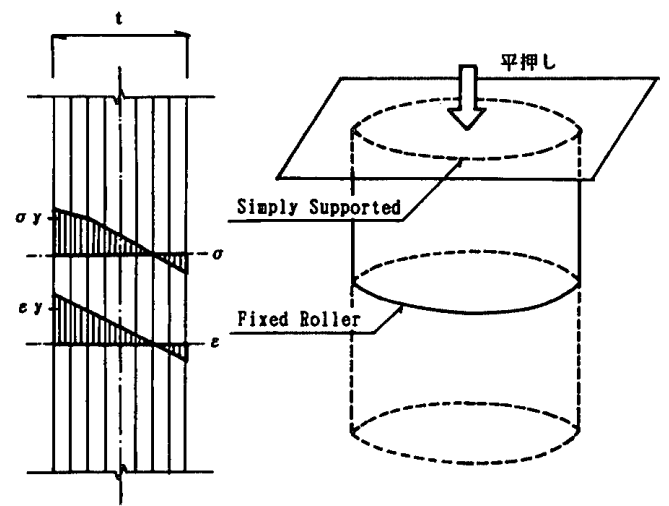

Fig. 14 要素分割方法および荷重載荷条件

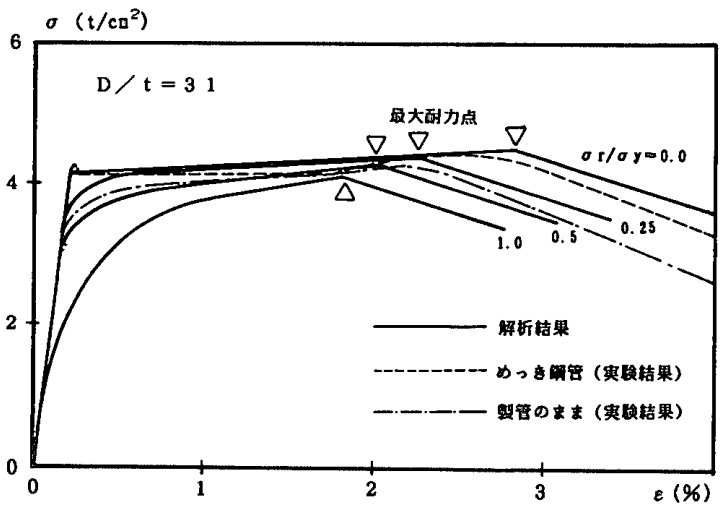

Fig. 15 弾塑性大変形解析による応力度-ひずみ度関係 (1)

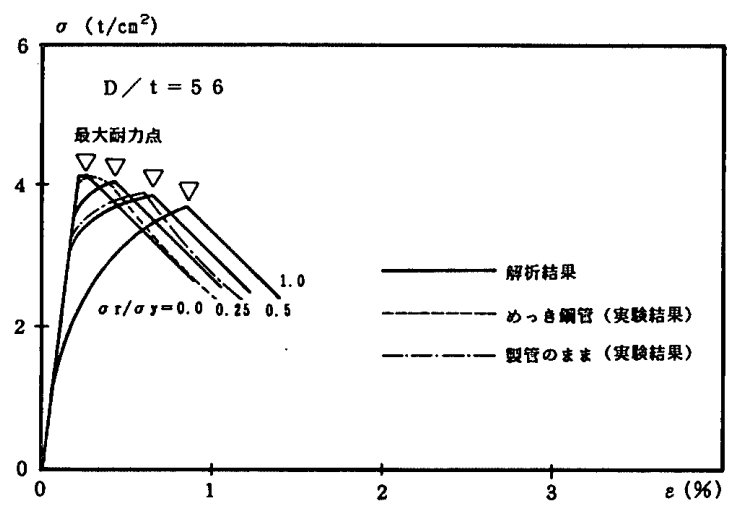

Fig. 16 弾塑性大変形解析による応力度一ひずみ度関係 (2)

\section{（1）解析の仮定事項}

(1) 応力度-ひずみ度関係は径厚比が 31 の STK 41 めっ き鋼管のそれから，Fig.13 に太実線で示す Bi-linear 型でモデル化する。このとき， $\sigma_{y}=4.13 \mathrm{t} / \mathrm{cm}^{2}, E_{s t}=$ $15 t / \mathrm{cm}^{2}$ とする。

(2) 応力度増分一ひずみ度增分関係式は弾性域では Hooke の法則, 塑性域ではPrandtl-Reuss の塑性流れ 理論に従うものとする。

(3) 円錐台形状のシェル要素を, Fig.14に示すように, 板厚さ方向に層分割し, 各層ごとに応力, ひずみは一定 とし von Mises の降伏条件式による弾塑性評価を行う。 (4)載荷は, Fig. 14 に示すように, 解析モデルの対称性
を考慮し，単純支持した端部に平押しの条件で強制変位 を加える方法で行う。

\section{(2) 解析ケース}

残留応力の測定結果では面内力としての残留応力はほ とんど存在せずほぼ一様な曲げ残留応力が存在してい る。本解析では，とりわけ值の大きい材軸方向の曲げ残 留応力を初期応力として直接与える方法により，鋼管の 荷重変形挙動を追跡する。このとき, 縁残留応力 $\sigma_{r}$ の 降伏応力度に対する比 $\sigma_{r} / \sigma_{y}$ は, $0.0,0.25,0.5,1.0$ の 4 種類, 径厚比は 31,56 の 2 種類を組み合わせた 8 ケ一 スについて解析を行う。

\section{(3) 解析結果}

Fig. 15 に径厚比 31 のシリーズにおける応力度-材軸 方向ひずみ度関係曲線を示す。ここに, 図中の実線は解 析結果を, 点線は製管のままの鋼管, 一点鎖線はめっき 鋼管の実験結果を示す。

応力度一ひずみ度関係は $\sigma_{r} / \sigma_{y}$ が $0,0.25$ と小さい場 合には, めつき鋼管の実験結果と同様，降伏棚を有する のに対し，0.5,1.0 と大きい場合には，製管のままの鋼 管の実験結果と同様に $\mathrm{RH}$ 型となる。また, 図中 $\Delta$ 印 で示す最大応力度あるいは最大応力度に対応するひずみ 度は, 残留応力の小さいほど大きくなる。

Fig. 16 に径厚比 56 のシリーズにおける忘力度-材軸 方向ひずみ度関係曲線を示す。

最大応力度は, 径厚比が小さい場合と同様, 残留応力 が小さいほど大きくなるが，最大応力度に対応するひず み度は逆に残留応力が小さいほよ゙大きくなる。

以上の結果は，いずれも実験結果と良い対応を示して いる。これより，めっき鋼管は，処理温度が約 460 度と 変態温度を下回ることから焼鈍効果は認められないもの の, 高温熱処理の影響により残留ひずみが一部解除され， 残留応力のない鋼管として扱えること，製管のままの鋼 管に比べて降伏応力度が大きくなることが, 奏験, 解析 両面から確認される。

\section{5. めっき鋼管の許容応力度設計対応の径厚比制限值の}

設定

許容応力度設計に対する限界径厚比は, 応力度が降伏 応力度に達するまで局部座屈を起こさないとし, 実験結 果等から,

$$
D / t \leqq 240 / F \quad F: \text { 規格強度 } t / \mathrm{cm}^{2}
$$

パラメー夕 $\alpha_{c}$ に換算すると 8.8 としている。

また，この規定は，残留応力，元たわみの影響により， 座屈応力度と径厚比の関係曲線が降伏点より相当低い点 でオイラ一曲線を離れることを考虑して定められた值で ある11)ことから，主には製管のままの鋼管を対象として いると考えられる。

したがって，めっき鋼管のように，強度特性が製管の 
ままの鋼管と異なるめつき鋼管については，新たに径厚 比制限値を設けることが必要となる。

ここでは, めっき鋼管の降伏応力度が製管のままの鋼 管のそれを 1 2 割上昇することを考慮して，パラメ一 夕 $\alpha_{c}$ の下限値として, $8.8 \times 1.1 \sim 1.2=10.0$, 径厚比制 限値として

$$
D / t \leqq 210 / F
$$

を提案する。

このとき，応力上昇率は，Fig. 10 に示すように，1.0 以上が確保され, 応力度が降伏志力度に達するまで局部 座屈を起こさないという基本条件が満足される。ちなみ に, $\alpha_{c}=10.0$ は, Fig. 11 に示す変形能力とパラメー夕 $\alpha_{c}$ の関係曲線の第一折点に相当し， $\alpha_{c}>10.0$ の領域で は変形能力は 1.0 を超える值となる。また, 耐力劣化勾 配は，Fig. 12 に示すように， $\alpha_{c}>10.0$ の領域では, $200 \mathrm{t} / \mathrm{cm}^{2}$ を下回る值となり安定した劣化挙動を示す。

\section{6. まとめ}

本研究において，得られた成果を以下に記す。

(1) 冷間成形鋼管は, 溶融互鉛めつき処理により一部残 留ひずみが解放され，特に值の大きい材軸方向の曲げひ ずみは $2 / 3$ 程度となる。

(2) 材軸方向の引張変形性状は, 溶融亚鉛めっき処理に より残留応力が小さくなることにより，降伏棚が現れる など変化する。

(3) 径厚比を変化させた短柱圧縮試験における、変形性 状あるいは応力上昇率, 変形能力とパラメ一夕 $\alpha_{c}$ との 関係から，溶融亚鉛めっき処理を受けた鋼管は残留応力 のない鋼管として取り扱える。また，降伏応力度は，製 管のままの鋼管に対し 10～20\% 程度高い值となる。

(4) 上記試験結果より，許容応力度設計に対するめつき 鋼管の径厚比制限值として，パラメータ $\alpha_{c} \geqq 10.0$, $D / t \leqq 210 / F$ を提案する。

\section{謝 辞}

本研究の一部は, 送電鉄塔用 60 キ口鋼開発の一環と して，新日本製鐵（株），日本鋼管（株），住友金属工業 (株)，川崎製鐵（株）と共同で実施したものである。 ここに，関係各位に深謝の意を表します。

\section{参考文献}

1）日本鋼構造協会標準委員会鋼管 JIS 小委員会：塑性加工 をうけた鋼材の機械的性質一STK 41 の引張ならびに圧 縮に対する機械的性質一，JSSC Vol. 6 No. 53，1970

2）加藤 勉, 秋山 宏, 鈴木弘之：軸王縮力を受ける鋼管 の塑性局部座屈耐力, 日本建築学会論文報告集, 第 204 号, 1973

3）加藤 勉, 青木博文：電気抵抗溶接鋼管のひずみ履歴亡 残留応力一短柱の圧縮試験における見掛けの応力ーひずみ 関係への影響について一，日本建築学会論文報告集，第 230 号, 1975

4）青木徹彦, 福本唀士：小口径電縫鋼管の統計的材料強度 特性と残留応力分布の評価, 土木学会論文報告集, 第 314 号, 1981

5）鈴木敏郎，小河利行, 加藤征宏, 栗本照彦：軸圧縮力を 受ける高張力銅管の強度性状に関する研究，日本建築学 会論文報告集，第 321 号，1982

6）越智健之, 黒羽啓明：冷間成形円形鋼管部材の耐力之変 形能の統計的評価，日本建築学会論文報告集，第 391 号, 1988

7）青木博文, 村田耕司：構造用鋼材の降伏点, 引張強さお 上び降伏比に関する統計的調查，日本建築学会論文報台 集，第 335 号，1984

8）藤本盛久，広木光雄，深沢 隆ほか：溶融要鉛めっき鋼 管の圧縮変形性状，日本建築学会大会学術講演梗概集， 1988

9）日本建築学会：建築耐震設計における保有酎力と変形性 能，技報堂，1981

10）社団法人鋼材俱楽部：中低層鉄骨建物の耐震設計法, 1978

11）加藤 勉：建築構造学体系 18 鉄骨構造，彰国社，1971

(1990 年 7 月 9 日原稿受理， 1990 年 12 月 5 日採用決定） 